\title{
Comparison between Use of Lysol and Effective Microorganism to Manage Odour at Municipal Waste Transfer Station
}

\author{
Nastaein Qamaruz Zaman, * Vong Yu Huan, Nurashikin Yaacof and Syafinah Yusoff \\ School of Civil Engineering, Universiti Sains Malaysia, \\ Engineering Campus, 14300 Nibong Tebal, Pulau Pinang, Malaysia \\ ${ }^{*}$ Corresponding author: cenastaein@usm.my
}

Published online: 15 November 2017

To cite this article: Qamaruz Zaman, N. et al. (2017). Comparison between use of Lysol and Effective Microorganism to manage odour at municipal waste transfer station. J. Phys. Sci., 28(3), 41-51, https://doi.org/10.21315/jps2017.28.3.3

To link to this article: https://doi.org/10.21315/jps2017.28.3.3

\begin{abstract}
Ampang Jajar Transfer Station (AJTS) in Pulau Pinang, Malaysia receives wastes from North and Central Seberang Perai, which are consolidated at AJTS before final disposal at Pulau Burung Sanitary Landfill located $40 \mathrm{~km}$ south. AJTS is located in an industrial area with the closest residences, Flat Ampang Jajar, about $300 \mathrm{~m}$ away. Efforts have been in place to manage odour nuisance by spraying solutions of Effective Microorganism (EM) and Lysol at the operation area of the AJTS. This study was conducted with the objective of verifying the effectiveness of EM and Lysol in odour control and their suitable spraying frequency. Solid wastes taken from AJTS were characterised in the laboratory for solids and moisture content, while its leachate was analysed for chemical oxygen demand (COD) and volatile fatty acids. A portion of the collected sample was also tested for odour concentration with and without EM and Lysol application. Laboratory analysis indicated that AJTS waste is highly degradable with $72 \%$ moisture content and $76 \%$ volatile solids, thus susceptible to odour production during decomposition. Acetic, butyric and propionic acid were present at concentrations of $3618 \mathrm{ppm}, 581 \mathrm{ppm}$ and 549 ppm respectively, higher than their respective odour threshold detection value of $0.21 \mathrm{ppm}$, $0.001 \mathrm{ppm}$ and $0.16 \mathrm{ppm}$. The sour and rancid smell attributed with the waste sample is contributed partly by the VFA content. AJTS sample in laboratory conditions was treated more effectively by Lysol (57\% odour reduction) compared to EM (24\% odour reduction). Lysol reduces malodour by masking the unpleasant "sour garbage" odour with a "soapy" scent instead, leading to a perceived "mildly unpleasant" (-1) hedonic tone. The current spraying of Lysol twice every $6 \mathrm{~h}$ at the AJTS is sufficient to manage odour to acceptable levels for 7 h after spray.
\end{abstract}

Keywords: Municipal solid waste, odour management, effective microorganism, Lysol, odour 


\section{INTRODUCTION}

Waste transfer station plays an integral part in municipal solid waste management system. It is usually constructed at a strategic place as it acts as a solid waste collection point from municipalities for compacting and transferring before the wastes are disposed at final disposal site. Hence, odour management is one of the critical issues facing the solid waste facilities officials as poor odour management will affect the citizens, workers and surrounding environment.

Odour from transfer stations occurs due to waste loading from waste trucks at dumping area and temporary storage of waste. ${ }^{1}$ As odour problems are very complex, have non-observable characteristics and may happen occasionally, repeatedly, continuously or vary in intensity, the subjective issues with finding a suitable odour control technique is no less complicated.

For Ampang Jajar Transfer Station (AJTS), Effective Microorganism (EM) is at first chosen as candidate in reducing the odour impacts on the surrounding environment. ${ }^{15} \mathrm{EM}$ spraying technique is implemented at waste tipping area as it is the principal source of odour pollution for the waste transfer station. However, as the amount of waste in Seberang Perai is rising every year (from 668 tonnes per day in 2005 to an estimated 1500 tonnes per day in 2020), ${ }^{2}$ spraying of chemical product such as Lysol is used occasionally to assist the odour suppression. Hence, this study is proposed to determine the odour removal efficiency in municipal solid waste facility by applying Lysol and EM respectively through simulation at laboratory.

The objectives of this study are to characterise the waste collected from AJTS, compare the odour removal efficiency between the commercial products, i.e., Lysol and EM and to determine the real-time odour concentration at AJTS.

\section{EXPERIMENTAL}

\subsection{Study Location and Sample Source}

The AJTS at Permatang Pauh, North Seberang Perai, Pulau Pinang, Malaysia is located at $5.414064^{\circ} \mathrm{N}, 100.405706^{\circ} \mathrm{E}$. The facility collects municipal solid waste from both Northern and Central Seberang Perai, to be consolidated and disposed of at the Pulau Burung Sanitary Landfill in Nibong Tebal, Pulau Pinang, about $40 \mathrm{~km}$ south. This study only involves the waste tipping floor area of the waste transfer building. The waste transfer building is semi-covered, with roof top for rain and wind cover, as well side entrances to allow vehicle access for the waste delivery. 


\subsection{Experimental Procedure}

This study involves both an experimental work on samples collected from the waste tipping floor area as well as on-site odour assessment of the same location. The experimental work involved waste characterisation as well as testing odour from the waste samples with and without Lysol and EM treatment. Lysol $(25 \%$, $\mathrm{pH} 10$ ) is a chemical disinfectant with benzalkonium chloride being the principal ingredient. ${ }^{3}$ The Lysol solution may cause eye and skin irritation, but not expected to be toxic if inhaled or ingested, nor carcinogenic. ${ }^{4}$

About $2 \mathrm{~kg}$ (wet weight) each of biodegradable solid waste samples collected from AJTS (devoid of glasses, plastics and non-biodegradable materials) was kept in a lidded 8 gallons plastic bucket under room conditions (no specific temperature or humidity control during bucket storage), and tested for odour treatment. Lysol and EM were sprayed into two separate waste buckets, at 9.30 am (onetime spraying) and at 9.30 am and $12.30 \mathrm{pm}$ (two-time spraying). The two-time spraying frequency imitates the current practice at AJTS, and further possibility of reducing the spraying to just once instead. Odour monitoring of the untreated and treated AJTS samples were done for every $2.5 \mathrm{~h}$, from 9 am until $5 \mathrm{pm}$. The test at each spraying frequency was repeated over two days.

For the on-site monitoring, odour concentration was measured at the AJTS waste tipping area. Measurement was taken every hour from 9.30 am till $4.00 \mathrm{pm}$ starting approximately 1 to $2 \mathrm{~h}$ after spraying of Lysol by the transfer station operators according to their routine odour and sanitation management procedure. The data collection at site was done twice per week, for two weeks.

\subsection{Waste Characterisation}

A $1.5 \mathrm{~kg}$ wet solid waste sample (only biodegradable materials) was collected from waste tipping area at AJTS and brought to the Environmental Laboratory of School of Civil Engineering, Universiti Sains Malaysia (USM) for laboratory analysis. The $1.5 \mathrm{~kg}$ solid waste sample was mixed manually and thoroughly and $1 \mathrm{~kg}$ collected sample was sorted out and its leachate extracted. The leachate simulation from solid waste was carried out based on leachate extraction technique developed by Qamaruz Zaman and Milke. ${ }^{5}$ The simulated leachate was analysed for chemical oxygen demand (COD) using Hach Spectrophotometer DR 2800. For COD analysis, the liquid samples were diluted based on the ratio of 1:500 to obtain the range of 3-150 $\mathrm{mg}^{-1} \mathrm{COD}$.

Volatile fatty acids (VFAs) in the liquid samples were analysed on gas chromatograph using GC Thermo Finnigan TRACE 2000 (USA) equipped with 
flame ionisation system (FID). A $1 \mu \mathrm{L}$ filtrated liquid sample was injected using AI 3000 auto sampler into an Agilent J\&W DB-FFAP column of $30 \mathrm{~m} \times 0.25 \mathrm{~mm}$ I.D. with $0.25-\mu \mathrm{m}$ film thickness in the split-less mode. Helium gas with constant flow rate of $0.75 \mathrm{ml} \mathrm{min}^{-1}$ was used as carrier gas. The GC oven temperature was raised at initial temperature of $100^{\circ} \mathrm{C}$ at rate of $8^{\circ} \mathrm{C} \mathrm{min}^{-1}$ until $200^{\circ} \mathrm{C}$ and held at $4 \mathrm{~min}$.

On the other hand, another $500 \mathrm{~g}$ of the solid waste left was used for measurement of moisture content, total solids (TS) and volatile solids (VS) based on the APHA Standard Methods. ${ }^{6}$ Approximately $500 \mathrm{~g}$ waste samples were distributed quarterly so that approximately one fifth of the sample $(100-125 \mathrm{~g})$ was left to form a representative sample.

\subsubsection{Odour characterisation}

In the laboratory, odour concentration was measured from gas samples withdrawn from the lidded buckets using a vacuum chamber into a $10 \mathrm{~L}$ Nalophan sampling bag. A SM100 Scentroid olfactometer was used to determine the odour concentration $\left(\mathrm{OU} \mathrm{m}{ }^{-3}\right)$ of the AJTS samples with and without treatment using a Yes/No method.

During the measurement of odour concentration, hedonic tone for the waste samples was also recorded. The nine-level scale of hedonic tone score (refer Table 1) suggested by German guideline VDI 3882 with scale ranging from minus four $(-4)$ to plus $(+4)$ is used to describe the odour nuisance. ${ }^{7}$ The + side of the scale represents the relative pleasantness while the - side of the scale represents the unpleasantness with 0 being neutral. The odour character was recorded based on an odour descriptor wheel. ${ }^{8}$ All odour analyses including odour concentration, hedonic tone and odour descriptor was based on the response of human nasal sensory.

\section{RESULTS AND DISCUSSION}

\subsection{Characterisation of Solid Waste from Transfer Station}

The simulated leachate from the waste samples collected from the AJTS contained between $41,500 \mathrm{mg}^{-1}$ to $61,500 \mathrm{mg} \mathrm{l}^{-1}$ of COD with an average value of $55,333 \mathrm{mg} \mathrm{l}^{-1}$ (6036 $\mathrm{mg} \mathrm{l}^{-1}$ standard deviation) from nine samples. The COD level observed in this study is in agreement with 55,000 $\mathrm{mg} \mathrm{l}^{-1} \mathrm{COD}$ of fresh leachate at Taman Beringin Transfer Station from a study by Ghasimi et al. ${ }^{9}$ The research stated that fresh leachate is generally characterised by high values of COD, $\mathrm{pH}$, ammonia nitrogen and heavy metals brings strong malodour. 
Table 1: Nine-level scale of hedonic tone score. ${ }^{7}$

\begin{tabular}{cl}
\hline Score & Perceived hedonic tone \\
\hline+4 & Very pleasant \\
+3 & Pleasant \\
+2 & Moderately pleasant \\
+1 & Mildly present \\
0 & Neutral / No odour \\
-1 & Mildly unpleasant \\
-2 & Moderately unpleasant \\
-3 & Unpleasant \\
-4 & Very unpleasant \\
\hline
\end{tabular}

Table 2: Volatile fatty acids of waste collected from AJTS waste tipping area.

\begin{tabular}{|c|c|c|c|}
\hline $\begin{array}{l}\text { Volatile fatty acid } \\
\text { (molecular weight, } \\
\left.\qquad \mathrm{g} \mathrm{mol}^{-1}\right)\end{array}$ & $\begin{array}{l}\text { Concentration } \\
(\mathrm{ppm})\end{array}$ & Characteristic odour & $\begin{array}{l}\text { Odour threshold } \\
\text { detection value } \\
(\mathrm{ppm})\end{array}$ \\
\hline Acetic (60) & 3618 & Sour, vinegar ${ }^{10}$ & $0.21^{10}$ \\
\hline Propionic (74) & 549 & $\begin{array}{l}\text { Slightly pungent disagreeable, rancid } \\
\text { odour }^{11}\end{array}$ & $0.16^{11}$ \\
\hline Isobutyric (88) & 14 & $\begin{array}{l}\text { Pungent odour like that of butyric acid, } \\
\text { but not as unpleasant }{ }^{12}\end{array}$ & $0.01^{12}$ \\
\hline Butyric (88) & 581 & Sweat, body odour ${ }^{13}$ & $0.001^{13}$ \\
\hline Isovaleric (102) & 38 & Disagreeable, rancid-cheese odour ${ }^{14}$ & $0.00000017^{14}$ \\
\hline $\mathrm{N}$-valeric (102) & 210 & $\begin{array}{l}\text { Sweaty, unpleasant and penetrating } \\
\text { odour, same as butyric acid }{ }^{14}\end{array}$ & $0.0000003^{14}$ \\
\hline Isocaproic (116) & 23 & Stench $^{14}$ & $0.000002^{14}$ \\
\hline N-caproic (116) & 186 & $\begin{array}{l}\text { Sharp, sour, rancid odour, goat-like } \\
\text { odour }^{14}\end{array}$ & $0.000002^{14}$ \\
\hline Heptanoic (130) & 55 & $\begin{array}{l}\text { Disagreeable, rancid odour; faint tallow- } \\
\text { like odour when spectroscopically pure }\end{array}$ & $0.64^{12}$ \\
\hline
\end{tabular}

High acetic acid at 3618 ppm was evident in the AJTS leachate from the waste tipping area, followed by butyric and propionic acid at $581 \mathrm{ppm}$ and $549 \mathrm{ppm}$, respectively (refer Table 2). The acetic, butyric and propionic acid naturally have low odour detection thresholds of $0.21 \mathrm{ppm}, 0.001 \mathrm{ppm}$ and $0.16 \mathrm{ppm}$, and considering their elevated concentrations are likely to have contributed to the sour-rancid-like smell observed from the waste. Occasional unpleasant vomit 
smell is contributed by butyric acid and propionic acid. The emission of such odorous compounds may cause odour nuisance to the community surrounding the waste transfer station. These acids (acetic, butyric and propionic acid) are lower molecular weight compounds, therefore are volatile and has higher potential for their emission to the atmosphere.

The waste from AJTS is wet with $72 \%$ moisture content and highly organic with $76 \%$ volatile solids. Given the wet and putrescible condition, odour is expected as the wastes start decomposing. High content of organic matters contributes to the production of foul-smelling products (e.g., $\mathrm{H}_{2} \mathrm{~S}$ and $\mathrm{NH}_{3}$ ) due to its degradation where wet garbage with higher organic content has higher malodour compared to dry garbage with lower organic content. ${ }^{10}$

\subsection{Odour Removal Between EM and Lysol Solutions with Different Spraying Frequencies}

Figure 1 shows odour concentration from the AJTS waste treated with one-time spraying of EM and Lysol solution at $9.30 \mathrm{am}$. For the EM treated waste pile, odour before treatment was $515 \mathrm{OU} \mathrm{m}^{-3}$ which later dropped to $430 \mathrm{OU} \mathrm{m}^{-3}, 2 \mathrm{~h}$ after EM was sprayed onto the waste. Odour was relatively constant at $390 \mathrm{OU} \mathrm{m}^{-3}$ for about another $2 \mathrm{~h}$ before ascending to $493 \mathrm{OU} \mathrm{m}^{-3} 7 \mathrm{~h}$ after spraying. The response of waste odour concentration indicates that the EM solution is effective to control odour for a period of $5 \mathrm{~h}$ with an odour reduction efficiency of $24 \%$.

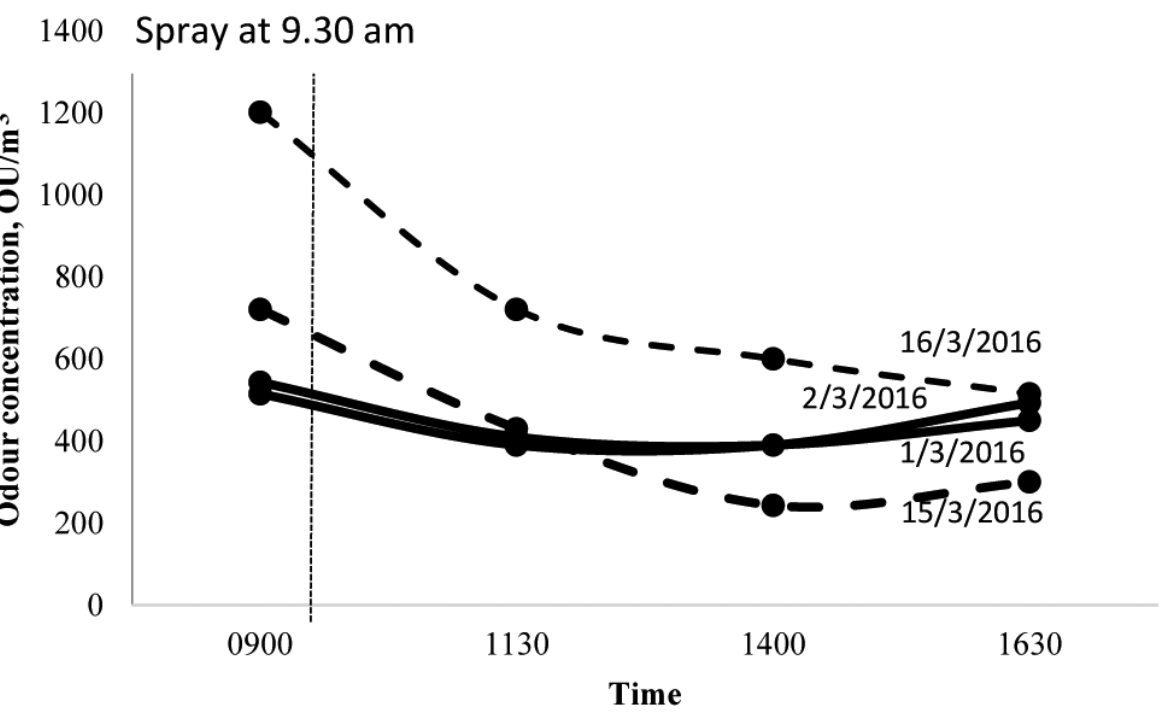

Figure 1: Odour concentration of AJTS waste treated with EM (-) and Lysol (- - ) spraying at $9.30 \mathrm{am}$ (dates indicated the experimental period). 
On the other hand, for the Lysol treatment, the odour removal was more drastic, from $1201 \mathrm{OU} \mathrm{m}^{-3}$ before treatment at $9.00 \mathrm{am}$ to $721 \mathrm{OU} \mathrm{m}^{-3}, 2 \mathrm{~h}$ after Lysol treatment. Odour continually decreases to a low $515 \mathrm{OU} \mathrm{m}^{-3} 7 \mathrm{~h}$ after spraying. With Lysol, odour control period was longer ( $7 \mathrm{~h}$ instead of $5 \mathrm{~h}$ with $\mathrm{EM}$ ), registering an odour reduction efficiency of $57 \%$.

Hedonic tone defines the pleasantness or unpleasantness of an odour, and is responsible for the perception leading to odour complaint. ${ }^{5}$ The hedonic tone for the EM application only demonstrated a slight improvement from -3 (unpleasant) to -2 (moderately unpleasant). The change in hedonic tone coincides with a move from an initial sour garbage smell to a fermenting smell after EM spraying. This shows good agreement with Higa and Chinen attributing the fermenting smell due to the reaction of fermenting types of microorganisms present in EM to suppress odour production. ${ }^{11}$ The hedonic tone markedly improved using Lysol from -3 (unpleasant) to -1 (mildly unpleasant). The initial offensive sour garbage sample was masked with a slight soapy smell that continued to a more neutral smell after long period of application. It seems that in the management of malodour, Lysol acts as a masking agent to reduce the odour issue. Marcovitch in his study also agreed that Lysol with antiseptic and antimicrobial properties has light soapy smell. ${ }^{12}$ For spraying EM twice, although odour concentration decreases more abruptly compared to spraying only once (refer Figure 2), hedonic tone shows not much improvement for both results of spraying once and twice. The hedonic tone decreases from -3 to -2 repeatedly with the same sour garbage smell to a fermenting smell after EM spraying. In addition, the behaviour of Lysol treatment was similar to the EM application, whereby the hedonic tone for spraying twice remains identical with spraying once. The hedonic tone decreases from -3 to -1 , again with sour garbage smell becoming more soapy and later to an almost neutral odour after long period of application.

The results of EM and Lysol application as shown in Figure 1 and Figure 2 indicated that Lysol offers a better option for odour treatment when sprayed onto the AJST waste compared to EM. The former also offers longer lasting odour suppression period up to $7 \mathrm{~h}$ compared to only $5 \mathrm{~h}$ with EM and with twice the odour removal efficiency. The result is reasonable as Golec et al. had discussed in their research that the breakdown of organic matter and fermentation of organic materials by lactic acid bacteria present in EM normally takes plenty of time. ${ }^{13}$ Compared to Lysol, EM does not mask the odour but it rapidly accelerates the activity of decomposition and altering the odour compounds in the solid waste to a fully-oxidised state. 


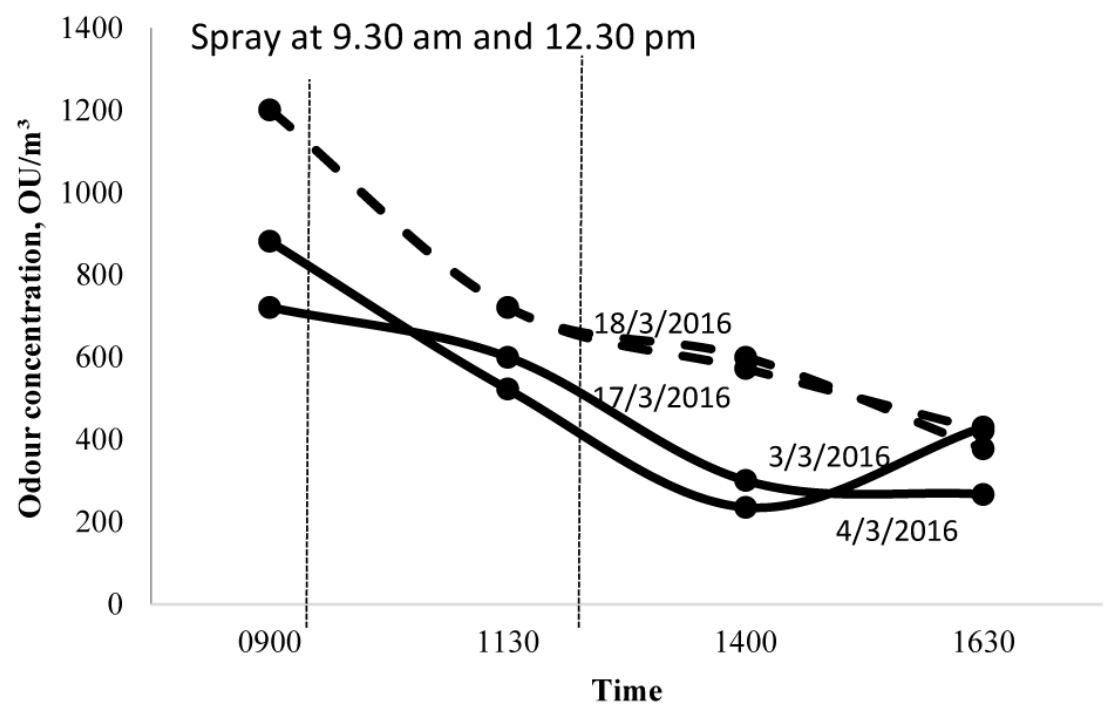

Figure 2: Odour concentration of AJTS waste treated with EM ( $(-)$ and Lysol ( $-\boldsymbol{-}$ ) spraying at $9.30 \mathrm{am}$ and $12.30 \mathrm{pm}$ (dates indicated the experimental period).

\subsection{Odour Emission at AJTS Waste Tipping Area}

Table 3 shows the odour concentration at the AJTS observed intermittently in two weeks. The waste tipping floor area was designed as partially enclosed area to manage dust, odour and windblown litter. During observation period, odour was higher especially after mid-afternoon (after $12 \mathrm{pm}$ ) where the ambient temperature was around $32^{\circ} \mathrm{C}-34.9^{\circ} \mathrm{C}$. The result is agreeable as National Solid Waste Management Association mentioned that at transfer station, odour issues are worse at warmer temperature, longer storage time and low wind conditions. ${ }^{10}$ Besides, United States Environmental Protection Agency also stated that odour level might increase during warm or wet weather. The effect of wind speed is less significant in this case due to partially enclosed design of the AJTS waste tipping floor. ${ }^{14}$

As demonstrated in Table 3, the concentration of odour at waste tipping area fluctuates within a limited range of values. The recorded lowest odour concentration was $681 \mathrm{OU} \mathrm{m}^{-3}$ whereas highest odour concentration was recorded as $1361 \mathrm{OU} \mathrm{m}^{-3}$.

The odour concentration measured at the site was comparable to the odour from AJTS waste sample, tested under laboratory conditions as demonstrated by Figure 3. A highest odour concentration of $1201 \mathrm{OU} \mathrm{m}^{-3}$ and a lowest value of 422 OU $\mathrm{m}^{-3}$ was observed, with peaks during noon about $2 \mathrm{pm}$. This corresponding behaviour of on-site odour concentration and laboratory odour data, indicates 
that the findings with regards to odour treatment found in the laboratory can be applicable for use at the AJTS.

Table 3: AJTS waste tipping area real time odour concentration.

\begin{tabular}{ccccc}
\hline Date & $23 / 3 / 2016$ & $25 / 5 / 2016$ & $30 / 3 / 2016$ & $1 / 4 / 2016$ \\
\hline Time & \multicolumn{4}{c}{ Odour concentration, $\mathrm{OU} / \mathrm{m}^{-3}$} \\
\hline 0900 & 1201 & 681 & 881 & 1041 \\
1000 & 721 & 721 & 721 & 681 \\
1100 & 1361 & 881 & 681 & 640 \\
1200 & 1201 & 1201 & 721 & 881 \\
1400 & 1361 & 881 & 1361 & 1041 \\
1500 & 1281 & 1201 & 721 & 1201 \\
1600 & 881 & 881 & 881 & 1361 \\
\hline
\end{tabular}

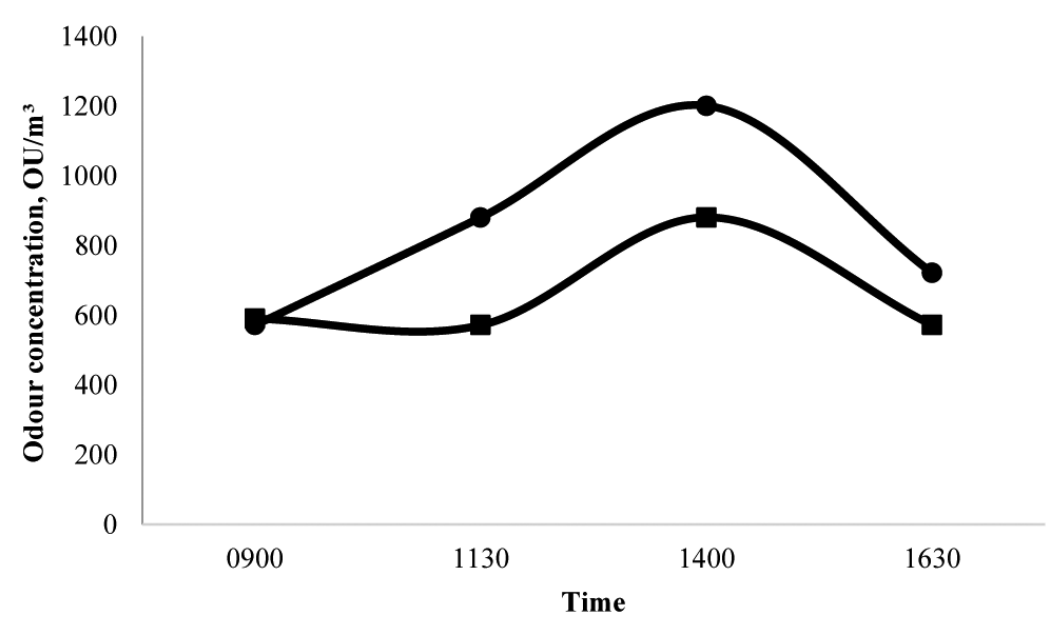

Figure 3: Odour concentration of duplicate AJTS waste sample measured in the laboratory.

\section{CONCLUSION}

The municipal solid waste at AJTS waste tipping area has abundant organic matters, evidenced by high COD (between 41,500 $\mathrm{mg}^{-1}$ to $61,500 \mathrm{mg}^{-1}$ ), volatile solids of $76 \%$ and moisture content of $72 \%$. The distinctive sour and pungent garbage smell at the waste tipping area can be explained by the high acetic acid (3618 ppm), butyric acid (581 ppm) and propionic acid (549 ppm) content, significantly beyond their odour detection threshold of $0.21 \mathrm{ppm}, 0.001 \mathrm{ppm}$ and $0.16 \mathrm{ppm}$ respectively. Lysol also has higher capability in reducing odour for a longer period 
of $7 \mathrm{~h}$ compared to just $5 \mathrm{~h}$ with EM. Spraying Lysol two times (morning and noon) within $6 \mathrm{~h}$ would be effective to reduce odour by $57 \%$, emitting a mildly unpleasant 'soapy' scent rather than an unpleasant sour garbage odour.

\section{ACKNOWLEDGEMENTS}

This work is funded by USM through RUI grant scheme 1001/PAWAM/814236 and under iconic grant scheme 1001/CKT/870023 for research associated with the Solid Waste Management Cluster. The authors are also thankful for the cooperation given by the AJTS personnel.

\section{REFERENCES}

1. Studer, R. G. et al. (2011). Systems and methods of processing and transporting waste. U.S. Patent 7, 882,683 B2, issued 8 February 2011.

2. United Nations Development Programme, UNDP. (2008). Malaysia developing a solid waste management model for Penang. Kuala Lumpur: UNDP.

3. Wijesinghe, L. P. \& Weerasinghe, T. K. (2010). A study on the bactericidal efficiency of selected chemical disinfectants and antiseptics. OUSL J., 6, 44-58, http://doi.org/10.4038/ouslj.v6i0.4113.

4. Reckitt Benckiser. (2008). Material safety data sheet. Retrieved from http://www.reckittprofessional.com/customer_services/msds/product/on 22 November 2016.

5. Qamaruz Zaman, N. \& Milke, M. (2011). VFA and ammonia emission during separate collection of residential waste as a measure of odor potential. Waste Manage., 32 (12), 2426-2430, https://doi.org/10.1016/j. wasman.2012.06.023.

6. American Public Health Association, American Water Works Association and Water Environmental Federation. (2005). Standard methods for the examination of water and wastewater, 21st ed. New York: American Public Health Association.

7. Belgiorno, V., Naddeo, V. \& Zarra, T. (2013). Odor impact assessment handbook. West Sussex: John Wiley \& Sons.

8. Suffet, I. H. \& Rosenfeld, P. (2007). The anatomy of odor wheels for odors of drinking water, wastewater, compost and the urban environment. Water, Sci. Technol., 55 (5), 335-344, https://doi.org/10.2166/wst.2007.196.

9. Ghasimi, S. M. D. et al. (2008). Batch anaerobic treatment of fresh leachate from transfer station. J. Eng. Sci. Technol., 3 (3), 256-264. 
10. National Solid Waste Management Association. (2004). Managing solid waste facilities to prevent odor. Retrieved from https://wasterecycling. org/images/documents/our-work/advocacy-issues/Odor-report.pdf on 19 January 2016.

11. Higa, T. \& Chinen, N. (1998). EM treatments of odor, waste water and environmental problems. Published paper for College of Agriculture, University of Ryukyus, Okinawa, Japan.

12. Marcovitch, H. (2005). Black's medical dictionary. London: A \& C Black.

13. Golec, A. F. C., Pérez, P. G. \& Lokare, C. (2007). Effective microorganisms: Myth or reality? Revista Peruana de Biología, 14 (2), 315-319.

14. United States Environmental Protection Agency. (2002). Waste transfer station: A manual for decision-making. Retrieved from https://www. adph.org/environmental/assets/EPAGuideforTransferStations 7-15.pdf on 16 February 2016.

15. Tan, D. (2016). Personal communication, 23 March. 